\title{
PARASITOLOGY
}

\section{PREVALENCE AND INTENSITY \\ OF ENDOPARASITIC NEMATODE \\ INFESTATIONS IN ADULT AND \\ JUVENILE SHARP-SHINNED HAWKS}

ROBERT GOSSELIN, Department of Biology, University of Regina, Regina, SK, S4S OA2; E-mail: <Rob.gosselin@hotmail.com>

\section{Introduction}

Few studies have examined the incidence of intestinal parasites in birds of prey. ${ }^{1}$ Raptor endoparasites do not usually cause disease in healthy individuals, although during times of stress they can sometimes lead to serious health problems. ${ }^{12}$ The main purpose of this study was to compare the prevalence and intensity of endoparasitic infestations in juvenile and adult Sharp-shinned Hawks (hereafter SSHA) collected in Saskatchewan and Manitoba. SSHA are widespread in the boreal coniferous forests of the central Canadian provinces and migrate south to winter in the southern USA, Mexico, and Central America. ${ }^{2}$ Over $90 \%$ of SSHA diet consists of small birds, but small mammals and insects also appear in their diet. ${ }^{2}$

\section{Methods}

I examined 18 frozen SSHA carcasses obtained opportunistically by the Royal Saskatchewan Museum. I dissected out complete digestive tracts and examined them visually to detect parasite infestations (Fig. 1, see inside back cover, top). The majority of specimens were collected in rural Saskatchewan during the years 1985 to 1997 , ranging from La Ronge to Consul, with one specimen from Manitoba (Table 1). Each bird was classified as juvenile or adult based on plumage characteristics. ${ }^{2}$ I sexed each specimen through examination of gonads and measurements of wing-chord, taillength, and tarsus. ${ }^{10}$ I weighed all birds to the nearest gram and scored the amount of fat in the furculum. Following Ferrer et al., I removed the digestive tract and preserved it in 95\% isopropyl alcohol. ${ }^{4}$ The esophagus, stomach, proventriculus, gizzard, and intestine were dissected, and their digestive contents, as well as mucosal surfaces, were examined under a dissecting microscope.

The prevalence and mean intensity of parasite infestation in the gut was quantified and compared between adult and juvenile birds. This follows the terminology of Margolis et al., where prevalence is the percentage of infested birds and mean intensity is the average number of parasites found within infested birds. ${ }^{8}$ Statistical analyses were performed using an unpaired $t$-test.

\section{Results \& Discussion}

Prevalence and mean intensity of parasitic infestation

Eighty-nine percent of adults were infested with parasites, whereas only $11 \%$ of juveniles were infested $(t=4.9$, $\mathrm{df}=16, \mathrm{p}<0.05$; Table 2). This finding may reflect the fact that adults would have had a longer period of time to acquire 
Table 1. Sharp-shinned Hawk specimen information with location and date of collection according to bird accession numbers assigned by the Royal Saskatchewan Museum. J: juvenile, A: adult, M: male, F: female.

\begin{tabular}{|c|c|c|c|c|c|}
\hline $\begin{array}{c}\text { Bird } \\
\text { Accession\# }\end{array}$ & $\begin{array}{c}\text { Year of } \\
\text { Collection }\end{array}$ & Location & Date & Age & Sex \\
\hline 14345 & 1985 & Indian Head, SK & 13 May & J & $\mathrm{M}$ \\
\hline 15118 & 1985 & Birch Hills, SK & Unknown & $\mathrm{A}$ & $\mathrm{F}$ \\
\hline 15118.10 & 1985 & Birch Hills, SK & Unknown & $\mathrm{J}$ & $\mathrm{M}$ \\
\hline 15502.006 & 1988 & La Ronge airport, SK & 16 August & $\mathrm{J}$ & $\mathrm{F}$ \\
\hline 15542.02 & 1989 & Assiniboia, SK & June & $\mathrm{A}$ & $\mathrm{F}$ \\
\hline 15753 & 1989 & Kronau, SK & 4 September & $\mathrm{J}$ & $\mathrm{F}$ \\
\hline 15751 & 1989 & Consul, SK & 23 September & $\mathrm{J}$ & $\mathrm{F}$ \\
\hline 16165 & 1990 & Wadena, SK & 16 October & $\mathrm{J}$ & $\mathrm{F}$ \\
\hline 17086.79 & 1993 & Paynton, SK & Unknown & $\mathrm{A}$ & $\mathrm{M}$ \\
\hline 17133.19 & 1994 & Regina, SK & 9 October & $\mathrm{A}$ & $\mathrm{F}$ \\
\hline 17682.3 & 1995 & La Rivière, MB & 1 May & $\mathrm{A}$ & $\mathrm{M}$ \\
\hline 17121.27 & 1995 & Yorkton/Melville area, SK & 12 May & $\mathrm{A}$ & $\mathrm{F}$ \\
\hline 17710 & 1997 & On farm X/E 18-22-21-W2, SK & 3 October & $\mathrm{J}$ & $\mathrm{F}$ \\
\hline Unknown & 2009 & Near Porcupine Plain, SK & 23 April & $\mathrm{A}$ & $\mathrm{F}$ \\
\hline 17701.10 & Unknown & Boundary Dam, SK & Unknown & $\mathrm{J}$ & $\mathrm{M}$ \\
\hline 17086.80 & Unknown & Unknown & Unknown & $\mathrm{J}$ & $\mathrm{F}$ \\
\hline 17729.3 & Unknown & Unknown & Unknown & $\mathrm{A}$ & $\mathrm{F}$ \\
\hline 15502.05 & Unknown & Unknown & Unknown & $\mathrm{A}$ & $\mathrm{F}$ \\
\hline
\end{tabular}

parasites from their diet than juveniles. Once acquired, endoparasites typically remain in the gut where they are able to grow and reproduce.

The mean intensity of parasites was one per juvenile and three per adult (Table 2). One adult bird had seven parasites, which was the greatest infestation observed. Kinsella et al. examined five SSHA for the prevalence and mean intensity of endoparasitic infestations and found both nematodes and trematodes infecting the gut, with the majority of parasites being trematodes. ${ }^{7}$ For nematodes and trematodes, respectively,

Table 2. Prevalence and mean intensity of nematode infestation in the gut between juvenile and adult Sharp-shinned Hawks (SSHA).

\begin{tabular}{|c|c|c|c|c|c|}
\hline SSHA Host & \multirow{2}{*}{$\begin{array}{c}\text { No. } \\
\text { Examined }\end{array}$} & \multicolumn{2}{|c|}{ Prevalence } & \multicolumn{2}{c|}{ Intensity } \\
\cline { 3 - 6 } & & No. Infested & $\%$ & Mean & Range \\
\hline Juvenile & 9 & 1 & 11 & 1 & 1 \\
\hline Adult & 9 & 8 & 89 & 3 & $1-7$ \\
\hline
\end{tabular}




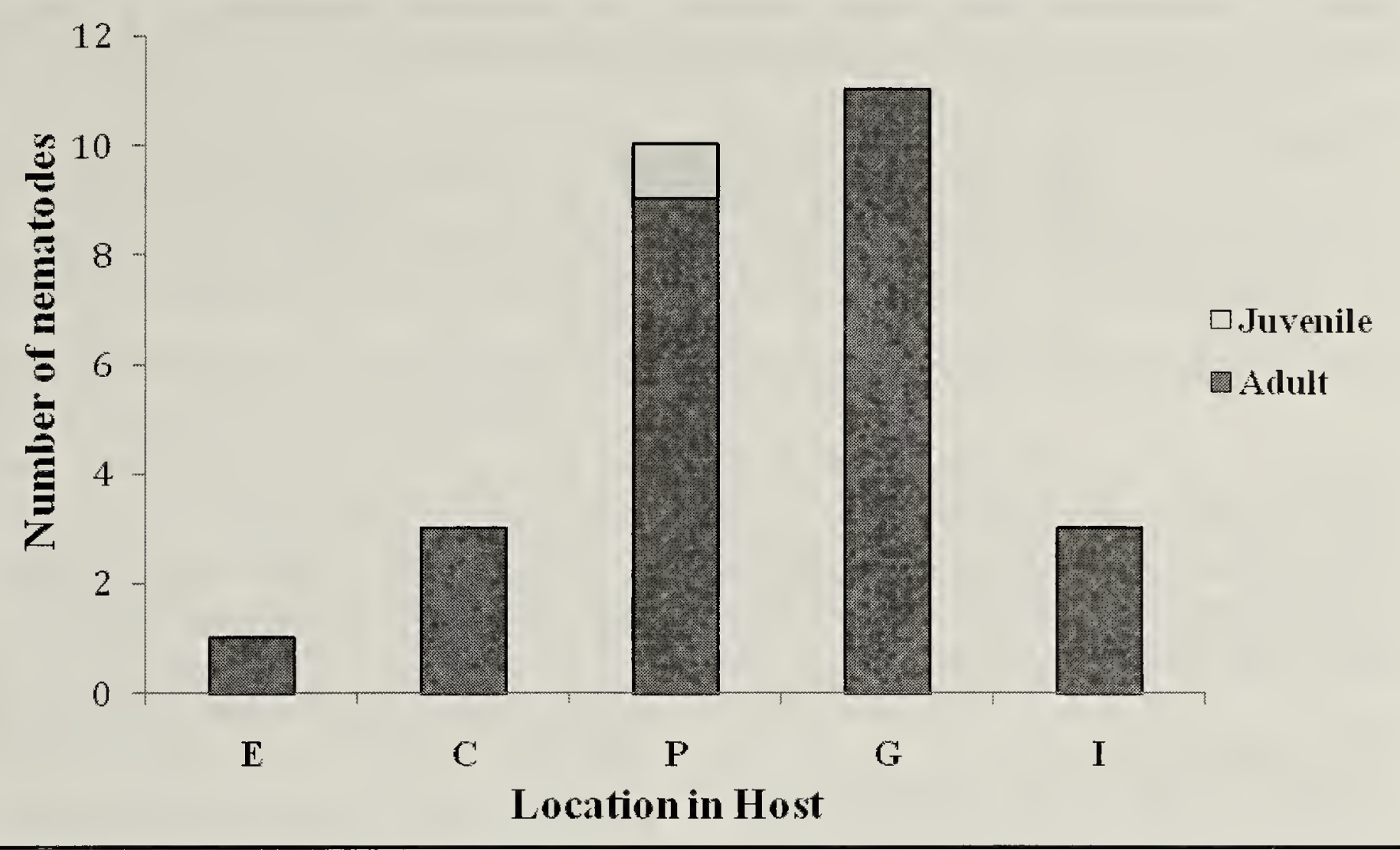

Figure 2. Number and location of nematodes found in juvenile and adult Sharp-shinned Hawks. E: esophagus, C: crop, P: proventriculus, G: gizzard, I: intestine.

the greatest mean intensity they found was three and 93 per bird and the greatest infestation was three and 291 per bird. Despite such high mean intensities of trematodes, Kinsella et al. did not observe any significant lesions nor implicate endoparasitic infestations as the cause of death in any of their specimens. ${ }^{7}$

Location and severity of parasite infestation

In total, I found 28 parasites among the nine adult and nine juvenile birds, all of them nematodes. Twenty-seven were found in adult birds, whereas only one was found in the juveniles. The majority of nematodes found were infesting the proventriculus or the gizzard (Fig. 2).

Smith stated that nematodes represent the largest group of endoparasites that infect birds of prey and that they are the most potentially pathogenic of the common raptorial parasites. ${ }^{12}$ However, most parasitic infections cause little or no stress to healthy individuals. Parasitic infections can cause health problems if raptors are stressed by injury or illness.

Other factors that contribute to parasitic infestations

Poulin analyzed the differential growth rates of helminths between male and female birds and found a small but consistent male bias in parasitic infections such that male hosts had greater prevalence of parasitic infestations than females. ${ }^{9}$ Sex-related differences in parasite infestations may be due to males and females differing with respect to their immune system, ${ }^{5,6}$ or due to different behaviours between males and females in territoriality, movement patterns, social interactions, and diet. ${ }^{9}$

I found no significant difference in the prevalence and mean intensity of parasitic infestations between males and females $(t=0.50, \mathrm{df}=16, \mathrm{p}>0.05$; Table 3); however, my sample sizes were small, limiting statistical power. Most studies that have documented parasitic infestations among birds of prey did not specify the sex of their specimens. ${ }^{1,7,11}$ 
Table 3. Prevalence and mean intensity of nematode infestation in the gut between male and female Sharp-shinned Hawks (SSHA).

\begin{tabular}{|c|c|c|c|c|c|}
\hline SSHA Host & No. & \multicolumn{2}{|c|}{ Prevalence } & \multicolumn{2}{c|}{ Intensity } \\
\cline { 3 - 6 } & Examined & No. Infested & $\%$ & Mean & Range \\
\hline Male & 5 & 3 & 60 & 2 & $1-4$ \\
\hline Female & 13 & 6 & 46 & 4 & $1-7$ \\
\hline
\end{tabular}

Doing so would allow researchers to explore sex-specific differences in levels of parasitism. This is important because a bias in favour of one sex could have a range of evolutionary implications. ${ }^{3}$

\section{Acknowledgements}

I thank Dr. Stephen Davis for providing the opportunity to conduct this project and for his help with dissections. I also thank Dr. Glenn Sutter of the Royal Saskatchewan Museum for allowing the use of frozen SSHA specimens and Peta White and John MacDonald from the University of Regina for providing lab space and dissecting equipment.

\section{BARTON, N. W. H., and D. C. HOUSTON. 2001. The incidence of intestinal parasites in British birds of prey. Journal of Raptor Research 35:71-73.}

2. BILDSTEIN, K. L., and K. MEYER. 2000. Sharpshinned Hawk (Accipiter striatus). In: Poole, A. (ed.) The Birds of North American Online. Ithaca: Cornell Lab of Ornithology, Ithaca, NY. Available at: http:// bna. birds.cornell.edu/bna/ species/482.

3. EWALD, P. W. 1995. The evolution of virulence: a unifying link between parasitology and ecology. Journal of Parisitology 81:659-669.

4. FERRER, D., R. MOLINA, J. CASTELLÀ, and J. M. KINSELLA. 2004. Parasitic helminths in the digestive tract of six species of owls (Strigiformes) in Spain. Veterinary Journal 167:181-185.

5. JOHN, J. L. 1994. The avian spleen: a neglected organ. Quarterly Review of Biology 69:327-351.

6. JOHN, J. L. 1995. Parasites and the avian spleen: helminths. Biological Journal of the Linnean Society 54:87-106.

7. KINSELLA, J. M., G. W. FOSTER, and D. J. FORRESTER. 1995. Parisitic helminths of six species of hawks and falcons in Florida. Journal of Raptor Research 29:117-122.

8. MARGOLIS, L., G. W. ESCH, J. C. HOLMES, A. M. KURIS, and G. A. SCHAD. 1982. The use of ecological terms in parasitology. Journal of Parasitolology 68:131-133.

9. POULIN, R. 1996. Sexual inequalities in helminth infections: a cost of being a male? The American Naturalist 147:287-295.

10. PYLE, P. 2008. Identification Guide to North American Birds Part II. Slate Creek Press, Point Reyes Station, California.

11. SANTORO, M., M. TRIPEPI, J. M. KINSELLA, A. PANEBIANCO, and S. MATTIUCCI. 2009. Helminth infestation in birds of prey (Accipitriformes and Falconiformes) in Southern Italy. The Veterinary Journal [Epub ahead of print]. doi:10.1016/j. tvjl.2009.07.001

12. SMITH, S. A. 1996. Parasites of birds of prey: their diagnosis and treatment. Seminars in Avian and Exotic Pet Medicine 5:97-105.

The world is always in movement. 